\title{
Heidegger and the Human Difference
}

\begin{abstract}
This paper provides a qualified defense of Martin Heidegger's controversial assertion that humans and animals differ in kind, not just degree. He has good reasons to defend the human difference, and his thesis is compatible with the evolution of humans from other animals. He argues that the human environment is the world of meaning and truth, an environment that peculiarly makes possible truthful activities, such as biology. But the ability to be open to truth cannot be a feature of human biology without making such pursuits as biology, mathematics, and philosophy a biological function of a certain species, Homo sapiens. To deny the human difference amounts to species relativism, which leaves the normativity of truth unexplained. To reconcile the human evolutionary heritage and the uniquely human openness to meaning and truth, this paper amplifies a distinction occasionally made by Heidegger between condition and cause.
\end{abstract}

KEYWORDS: phenomenology, evolution, truth, normativity, philosophy of biology

In I859, Charles Darwin entitled the third chapter of the Origin of Species, 'The Struggle for Existence' (I952a: 32). A year later, it was translated into German as 'Kampf ums Dasein' (Krell 1993: 48). Every single species, humans included, emerged from natural selection. In The Descent of Man, Darwin argued that humans differ in degree, not in kind, from other animals: 'Nevertheless the difference in mind between man and the higher animals, great as it is, certainly is one of degree and not of kind' (I952b: 3I9). In the animal kingdom, there is a gradient of rationality, language, religion, and handicraft; human beings are just another grade of the continuum. ${ }^{\mathrm{I}}$ In the I920s, Martin Heidegger gave the German term, 'Dasein', a markedly different sense. Instead of naming generic existence, it designates the entity that each of us is, an entity distinct from other kinds of entities in that it is open to the intelligibility or meaning of all entities. We who partake in Dasein can 'apprehend something as a being' (GA 29/30: 384/264). ${ }^{2}$ Throughout

I am thankful to Robert Wood and several anonymous referees for their comments on earlier versions of this paper.

I Regarding religion, Darwin sets aside the kind of views of the divine one may have from revelation and from philosophical speculation. He then suggests that the natural religious sentiment shared by all humankind can also be found in some higher animals: 'we see some distant approach to this state of mind in the deep love of a dog for his master, associated with complete submission, some fear, and perhaps other feelings' (I952b: 303 ).

2 Unless otherwise noted, I will cite the volume in Heidegger's collected works, Gesamtausgabe (GA), followed by the pagination of the German edition and the pagination of an English translation, if one is available. 
his works, Heidegger repeatedly says that Dasein is separated from all animals by 'an abyss', and he even denies that the human body is an organism (GA 9: 324/247). There is no continuum embracing animals and humans; rather, there is a difference in kind. With this position, he seems to deny Darwin's insight that human beings have evolved from other life forms.

Heidegger's position seems shocking even to some philosophers in the continental tradition. Calarco (2008) accuses Heidegger of 'metaphysical anthropocentrism', and Mitchell (20I I: 74-85) holds that childhood development undermines the human difference. Other philosophers are just as scandalized. MacIntyre (I 999: 47-48) finds Heidegger's difference in kind refuted by research on the higher animals, such as dolphins and chimpanzees; he thinks erasing the difference leads to a greater awareness of our animal vulnerability and consequent need for the virtues. Searle (2005: 329) holds that Heidegger's account of Dasein lacks credibility, because among other things he does not relate Dasein to evolutionary theory.

I think these objections are misguided. Heidegger has good reason to defend the human difference, and his thesis is compatible with the evolution of humans from other animals. In this paper, I first trace his reasoning. His position rests on an informed understanding of biology that finds confirmation in the recent biological theory of niche construction. Environments exist only when their corresponding organisms exist, because the biology of the organism specifies which features of the physical world will constitute the organism's environment. Heidegger's contention that humans differ from other animals stems from his belief that the human environment must differ in kind from the environment of other animals. He argues that the human environment is the world of language and truth, an environment that peculiarly makes possible truthful activities, such as biology. But the ability to be open to truth cannot be a feature of human biology without making such pursuits as biology, mathematics, and philosophy a biological function of a certain species, Homo sapiens. To deny the human difference amounts to species relativism and leaves the normativity of truth unexplained. To reconcile Heidegger's thesis concerning human uniqueness with the Darwinian insight into common ancestry, I amplify a distinction occasionally made by Heidegger between condition and cause.

It is trivially true to say that human beings differ in kind from other animals when 'kind' is taken as synonymous with biological species. Obviously and uninterestingly, Homo sapiens is different from goldfish and magpies. It is also trivially true to say that the difference between Homo sapiens and other living primates is great, such that there is an observable gap in behavior and abilities. The question concerns not whether there is a difference but rather the character of the difference. Is what is distinctively human, i.e., openness to truth, intelligible according to biological principles? Or does it require a different mode of inquiry to make sense of it? Heidegger thinks that when it comes to humans as Dasein, biology can make no sense of us; instead, it falls to philosophy to render intelligible our unique openness to truth in which something like biological inquiry is possible. I am not interested in mounting a 
general case for the human difference in kind. Rather, I want to show that the criticism leveled against Heidegger's position is unconvincing. And the crux of the issue, for him, is that with Dasein comes a new domain, a dimensional difference, that calls for its own principles of analysis. Specifically, only Dasein relates to being or intelligibility. And this domain is normative; it makes demands on us to get things right.

\section{The Reciprocity of Niche Construction}

Darwin's metaphor of adaptation suggests that the animal must fit itself to a preexisting environment. Heidegger follows the biologist Jakob von Uexküll (I92I) and maintains that environments are in fact a function of the kind of organism in question: 'The organism is not something independent in its own right which then adapts itself. On the contrary, the organism adapts a particular environment into it in each case, so to speak' (GA 29/30: $384 / 264$; for the same claim, see also GA 36/37: 210/160). That is, different kinds of organisms establish quite different environments; they do not first exist and then conform to an environment. This criticism of Darwin's metaphor expresses a fundamental principle: animal and environment are related reciprocally.

Heidegger's principle of reciprocity, inspired by Uexküll, finds support in the contemporary model of niche construction, advocated by biologists Richard Lewontin (2000), F. John Odling-Smee, Kevin Ladland, and Marcus Feldman (2003) and also Jeremy Kendal and colleagues (20II). According to this theory, the organism in fact constructs its environment by determining which features of the physical world are relevant to it and by changing the physical world itself (Lewontin 2000: 4I-68). As Lewontin puts it:

Just as there can be no organism without an environment, so there can be no environment without an organism. There is a confusion between the correct assertion that there is a physical world outside of an organism that would continue to exist in the absence of the species, and the incorrect claim that environments exist without species. The earth will precess on its axis and produce periodic glacial and interglacial ages, volcanoes will erupt, evaporation from oceans will result in rain and snow, independent of any living beings. But glacial streams, volcanic ash deposits, and pools of water are not environments. They are physical conditions from which environments may be built. An environment is something that surrounds or encircles, but for there to be a surrounding there must be something at the center to be surrounded. The environment of an organism is the penumbra of external conditions that are relevant to it because it has effective interactions with those aspects of the outer world. (2000: 49) 
Because the number of potential environments is unlimited, it is not the environment that selects the organism so much as the organism that selects the environment. The nature of the organism determines which environment will be relevant for it. Lewontin (I99I: 8-9) argues that as helpful as the Darwinian metaphors of adaptation and struggle for existence were in his day, they need to be modified today in favor of more complex understanding of the relation of organism and environment. Now, the metaphor of construction might appear just as unilateral as the metaphor of adaptation, but Lewontin (2000: I 26) points out that the environment does affect the organism as well: 'Thus organism and environment are both causes and effects in a coevolutionary process'. ${ }^{3}$ There is substantial agreement between Heidegger and Lewontin concerning the lack of reciprocity in Darwin's adaptation metaphor.

\section{Constructing the Human Niche}

What is the environmental niche that opens up with the human being? In The Symbolic Species, the anthropologist Terrence Deacon (I997: 22) writes: 'Though we share the same earth with millions of kinds of living creatures, we also live in a world that no other species has access to'. In this world, we can range over absent things, including nonexistent things, and consider the way things could have gone better. 'In a real sense, we live our lives in this shared virtual world' (23). Heidegger agrees that humans uniquely relate to symbolic meaning, which is the domain of being, truth, and language. But he insists that we cannot understand this domain in terms of the interplay of biological and physical forces. He does not wish to deny, of course, that we can analyze the human environment biologically. For example, we can point out that one of the significant things determined by our DNA is our relative size, which makes us immune to the Brownian motion that batters bacteria and makes us big enough to feel the effects of gravity, big enough to generate sufficient kinetic energy to drive a spear into a wooly mammoth (Lewontin I99I: 9I). However, merely being of a certain size and relating to certain physical forces relevant for specifying our means for survival is not yet what Heidegger means by world.

Although the theory of niche construction brings a more dynamic understanding of the relation of the animal and the environment, it is inadequate as a characterization of world. For what is at issue is not an ontic or causal relation that supports the survival of the human being, but instead openness to truth, which shows itself only to ontological investigation. Despite this difference, Heidegger employs the following analogy: as animal is to environment, so Dasein is to world. The analogy is fraught with danger, for it might be taken to suggest that in some way the ontological can be explained in terms of the ontic, that somehow world admits of a biological explanation. But the analogy serves to heighten the reciprocity of the ontic and ontological relations, not to marginalize the difference between them.

3 Odling-Smee et al. (2003: 19) express the reciprocity as follows: 'From the beginning of life, all organisms have, in part, modified their selective environments, and their ability to do so was, in part, a consequence of their naturally selected genes'. 
As the animal is correlated with a particular domain termed an environment, so the human is correlated with a particular domain termed world. In I9 I9, Heidegger speaks of the human environment as the world of interpersonal meaning:

In the experience of seeing the lectern something is given to me from out of an immediate environment [Umwelt]. This environmental milieu (lectern, book, blackboard, notebook, fountain pen, caretaker, student fraternity, tram-car, motor-car, etc.) does not consist just of things, objects, which are then conceived as meaning this and this; rather, the meaningful is primary and immediately given to me without any mental detours across thing-oriented apprehension. Living in an environment, it signifies to me everywhere and always, everything has the character of world. (GA 56/57: 72-73/6I)

In Being and Time, Heidegger calls attention to the uniqueness of this human environment. After provisionally exhibiting world, he notes that it is the condition for the possibility of truth. Dasein, as that entity characterized by being-in-the-world, provides the site for things to appear in their truth:

Newton's laws, the principle of contradiction, any truth whateverthese are true only as long as Dasein is. Before there was any Dasein, there was no truth; nor will there be any after Dasein is no more. For in such a case truth as disclosedness, uncovering, and uncoveredness, cannot be....

To say that before Newton his laws were neither true nor false, cannot signify that before him there were no such entities as have been uncovered and pointed out by those laws. Through Newton the laws became true and with them, entities became accessible in themselves to Dasein. Once entities have been uncovered, they show themselves precisely as entities which beforehand already were. Such uncovering is the kind of Being which belongs to 'truth'. ([I927] 200I: 227/269)

Dasein's environment, world, allows entities to be available in their meaning and truth. Absent Dasein, this environment would not exist even though the entities in it would. As Carman (2003: I 5 5-203) argues, Heidegger advocates a realism about entities and their causal properties, which are as they are independent of Dasein. Heidegger does, however, think that being, intelligibility, truth, and meaning are dependent on Dasein. In this sense, Dasein constructs its niche although the niche also determines what it is to be Dasein. The principle of reciprocity, then, applies to the human being as Dasein, who provides the place for things to appear in truth.

Heidegger thinks classical philosophy sees the connection of Dasein and being quite clearly. Plato maintains that to be human, a soul must have seen being (GA 36/37: 206/I 57). Aristotle thinks the human soul is 'in a way all entities', and Thomas Aquinas understands transcendental truth as rooted horizontally in the 
capacity of the human intellect to apprehend all things ([I927] 200I: I4/34). Dasein's special status, Heidegger concludes, 'has obviously nothing in common with a vicious subjectivizing of the totality of entities' ([I927] 200I: I4/34). The reciprocity of being and Dasein, then, is not a residue of modern idealism. It concerns the classical insight that being or meaning is correlated with mind. Heidegger does maintain that the tradition has two critical shortcomings: it fails to identify world as the place where the correlation occurs, and it does not experience the dynamic reciprocity inherent in the connection of Dasein and being (Engelland 2012). As Darwin misses the reciprocity of animal and environment, so the transcendental tradition misses the 'remarkable "relatedness" backward or forward' concerning Dasein and being ([I927] 200I: 8/28). To make sense of this relatedness, Heidegger comes to underscore that world is a fundamentally historical phenomenon in which our conception of intelligibility changes from era to era. For example, he thinks that the contemporary Western world relates to nature in a very different way than the ancient Greeks. Indeed, Heidegger even goes so far as to say that the contemporary world suffers a kind of darkening that, among other things, offers up nature as raw material for industrial exploitation rather than as fodder for poetry and contemplation (GA 40: $34 / 47$ ). The specifics of these historical claims are no doubt controversial, but the general idea that different human cultures and ages afford a different horizon for philosophical thought need not be. Nonetheless, if Heidegger's later historical meditations seem unappealing, his account of world and the human difference can still be maintained on the basis of his earlier, purely transcendental conception of world.

\section{A Difference in Kind}

The human environment is the domain of language and truth. Whether there is a difference in kind turns on the question of the relation of Dasein's world to the environments of other animals. Searle (2005: 329-33) finds problematic Heidegger's claim that the 'transcendental operator' is more basic than the brute facts discovered by science. But if we follow the suggestion of Lewontin that there is no niche apart from the organism that constructs the environment, we can see what Heidegger has in mind. Things would indeed exist without Dasein, but they could not manifest themselves in their intelligibility. Dasein's environment differs in kind from that of other living things because it allows things to show themselves as they are and not just in terms of biological relevance. Dasein taps into the normative dimension of truth. Our unique nature helps construct the peculiar environment in which there can be truthful activities, such as biology.

The phenomenological movement began with Husserl's refutation of psychologism ([I900] 2000a) and discovery of intentionality ([I90I] 2000b). Truth cannot be explained in terms of psychology, for psychology itself presupposes it. To maintain otherwise is to fall prey to the absurdity of relativism. Husserl ([I9I3] I998: I I I) discovers 'a veritable abyss [Abgrund]' between constituting and 
constituted, with the result that the human becomes bifurcated into a transcendental and empirical ego. Heidegger never abandons Husserl's refutation of psychologism although he does find problematic the ideal-real divide Husserl outlined as the alternative ([I927] 200I: 2I 5-I 7/258-60). Heidegger takes Husserl to task for not realizing that the discovering of intentionality and with it of categorial intuition involves a new awareness of what it means to be human: 'The insight into intentionality does not go far enough to see that grasping this structure as the essential structure of Dasein must revolutionize the whole concept of the human being' (GA 26: I67/I 33). To be human means to be open to the availability of things in their intelligibility (Crowell 2002). If we deny that Dasein differs in kind from other things, then we fall prey to a kind of relativism that defines truth as the attribute of a given species. ${ }^{4}$ Instead, Heidegger insists that it is the peculiarity of Dasein that it is the steward of intelligibility, and it is this not qua being-in-an-environment but qua being-inthe-world. Heidegger attempts to think of the human being, intentionality and all, as a single being that therefore retains an abyss in relation to other living beings.

Now, it might appear that Heidegger's appeal to a transcendental operator, Dasein, itself falls prey to relativism. He addresses this in the 1927 text, Basic Problems of Phenomenology, by clearly distinguishing the meaning of something unveiled or made true from its uncovering or being made true:

For nature to be as it is, it does not need truth, unveiledness. The content intended in the true proposition ' 2 times $2=4$ ' can subsist through all eternity without there existing any truth about it. So far as there is a truth about it, this truth understands precisely that nothing in what it means depends on it for being what it is. (GA 24: 3 I $5 / 220-2 \mathrm{I}$ )

For Heidegger, there are no eternal truths, because, on his view, there is no eternal intellect for whom such truths could be true. However, the content of ' 2 times 2 $=4$ ' shows itself to us as existing independent of its being taken to be true. Dasein can access meaning that transcends the fact of its being accessed, but only Dasein allows that meaning to be true or normative. As Steven Crowell has argued, Heidegger's Being and Time develops a comprehensive account of normativity. Unlike Christina Korsgaard's Kantian conception, which appends self-reflection to animal inclinations, Heidegger's conception is rooted in the unitary phenomenon of care. Angst, guilt, and a certain anticipation of death provide the existential framework for making sense of the normativity of truth. Dasein, thrown into the world, finds itself beholden to the entities it finds there. As Crowell (2013: 240) puts it: "This does not mean that entities depend on Dasein. But their "being"that is, any characterization of them as something-is possible only if Dasein holds them up to constitutive standards, or satisfaction conditions, for being the things they are'. Dasein peculiarly allows entities in the world to be intelligible as the things they are such that the intelligibility of things is normative. Such normativity

4 Heidegger writes, 'The existential analytic of Dasein comes before any psychology or anthropology, and certainly before any biology' ([I927] 200I: 45/7I; cf. [I927] 200I: II/3I). On this point, see Husserl ([I900] 2000a: sec. 36 and 38 ). 
makes no sense if openness to truth is regarded as a biological function along the lines of metabolism and reproduction.

Nietzsche provides a good foil to Heidegger, for he too recognizes the dependency of truth on the human being. However, he follows Darwin in denying the human difference. Hence, he concludes that truth and knowledge is of only relative standing:

Between ourselves: since no one would maintain that there is any necessity for men to exist, reason, as well as Euclidean space, is a mere idiosyncrasy of a certain species of animal, and one among many. (I968, n. 5 I 5, my emphasis. On the importance of Darwin for Nietzsche, see Stegmaier [1987: 264-87])

Heidegger agrees that there would be no mathematics and rationality without Dasein, but he saves their truth by means of Dasein's difference in kind. Such a move is not a metaphysical anthropocentrism but rather fundamentally an ontoor aletheia-centrism (GA 9: 334/254). Dasein is different only because being and truth are different. Because being and truth need Dasein but are not an accident of a biological species (and thus relative), Dasein comes to the fore, no longer as an organism, but as the agent of truth. ${ }^{5}$ The special character of being and truth as the human environment necessitates a difference in kind: 'In its essence, language is not the utterance of an organism; nor is it the expression of a living thing. Nor can it ever be thought in an essentially correct way in terms of its symbolic character, perhaps not even in terms of the character of signification. Language is the clearingconcealing advent of being itself' (GA 9: 326/248-49). Language logically belongs to the concept of truth and world. The point is taken up by Gadamer (I998: 438-56), who notes the contrast with Nietzsche. McDowell, citing Gadamer's presentation of the distinction between environment and world, argues (I994: I I4-I9) that the experience of objective reality presupposes the kind of conceptual capacities uniquely enjoyed by human beings. The difference is that McDowell views world as a function of the spontaneity of the understanding rather than of language.

Consider the kinds of principles at work in making sense of the following situation: Darwin is at work in his study. Light streams into his window from the sun some 93 million miles away at an exact speed identifiable by physics. Now, Darwin's stomach rumbles. He's hungry. He may get up and grab a snack if he wishes. If he doesn't, he'll survive although eventually he'll have to eat to replenish the energy his body needs to metabolize. He decides to wait to eat dinner with his family. For Darwin as a human being, the felt desire is normative: one should fulfill it, although how and why, and even whether it will be is not determined (in special circumstances, one might forgo food for one's child or one's God). Now Darwin focuses on his work. He weighs the considerations for and against and decides that humans differ in degree and not in kind from other animals. In making this judgment, he not

5 I take the phrase, 'agent of truth', from Sokolowski (2008: I 4), who writes, 'There could not be a disclosure without me or someone like me there to achieve and receive it, and I am there not merely as a biological organism or a psychological center of consciousness, but as an agent of logic and verification'. 
only wants to get it right, but he should get it right even though getting it wrong will not imperil his survival. Nonetheless, it is possible to get it wrong. Unlike the physical domain in which laws are infallibly followed or the biological realm of necessity, the normativity of truth is not inviolable. If an engineer makes a miscalculation, a bridge collapses; if an animal does not eat, it will die; but if a scholar misunderstands his topic, a different sort of thing happens. When the error is pointed out to him, he will change his mind because, as Dasein, he has care for the truth. Openness to truth is not the sort of thing that admits of biological explanation.

\section{The Theoretical and Empirical Questions}

It is helpful to distinguish two interrelated questions. First, there is the theoretical question: Is openness to truth intelligible in biological terms? If yes, the manifest differences in behaviors and capacities between humans and other animals is a difference in degree, not a difference in kind. If no, the manifest difference reflects a difference that can only be registered by philosophy (not by a biologist qua biologist but only by a biologist qua philosopher). As I argued above, it is necessary to answer no in order to avoid relativism and make the normativity of truth intelligible. Second, there is a separate empirical question: Are humans alone open to truth? Granting the difference in kind between the entity open to truth, Dasein, and biological processes, it is still an open question how many species or members of species partake of Dasein. Heidegger's case for the first question is extremely strong, and it can be because it is a purely theoretical issue. The case for the second is not only theoretical but also empirical. It is still a strong case, but as a hybrid one it is necessarily open to revision. Heidegger asserts what could be called the singularity thesis: humans alone are open to truth. Clever though they may be, dolphins, dogs, and chimpanzees lack language and are therefore doing something other than what Dasein does. Heidegger also underscores the historical character of world that happens thanks to language. Hence, species without language are species without historical openness to truth.

By calling this second question 'empirical' I do not mean it is a position remanded to the special sciences, but rather that it is a question that requires cooperation among philosophy and the sciences to answer. We know about our environment because each of us is a Dasein who dwells in it: 'all man's questioning about man is in the first and last instance a matter of the existence of man in each specific case, (GA 29/30: 407/28I). Philosophical method allows us to conceptualize the human way of being. In Being and Time and contemporary lecture courses, Heidegger calls this method 'formal indication' (Dahlstrom I 994 and Shockey 20I0). Terms such as 'care' or 'being-in-the-world' are invitations for each of us to turn to our own environments and register the distinctions that show up there. Formal indication, however, is not available for investigating other kinds of beings. How do we know what it's like to be a nonhuman animal? How can we discern its environment?

In the I929/30 lecture course, Heidegger puzzles long and hard concerning the question how we can access the experiential life of animals to discover what concepts if any might be operative. He thinks we know about Dasein by 
thoughtfully being one and that we know about other animals by a form of analogical reasoning based on our own environmental experience and on empirical investigation (McNeill I999: 2I I-20). On the basis of this approach, he advances his famous thesis that in comparison with Dasein, animals are poor in world (GA 29/30: 263/I77). Animals are bound to their respective environments and cannot apprehend something as something:

For it is not simply a question of a qualitative otherness of the animal world as compared with the human world, and especially not a question of quantitative distinctions in range, depth, and breadthnot a question of whether or how the animal takes what is given to it in a different way, but rather of whether the animal can apprehend something as something, something as a being, at all. If it cannot, then the animal is separated from man by an abyss. (GA 29/30: $383-84 / 264$ )

Animals access an environment with beings, but only Dasein can experience those beings as beings. A dog might sniff a leaf lying in the grass, but Dasein understands the leaf to be a part of the tree that, among other things, carries out photosynthesis and the falling of which signals the change of seasons. 'The animal certainly has access to ... and indeed to something that actually is. But this is something that only we are capable of experiencing and having manifest as beings' (GA 29/30: $390 / 269)$. Animals are captivated by the disinhibition of their drives. The character of the surroundings they find themselves in is specified by the panoply of drives, and their behavior is specified in terms of the release of these drives. Features of the environment show up only in the ambit of the captivated animal interest (GA 29/30: 376-378/258-260). By contrast, the human world allows entities to be encountered in their intelligibility, as the sorts of things they are. It is important to note that Heidegger does not regard animal essence as poor in itself but only in comparison with Dasein (GA 29/30: 394/27I).

Heidegger also focuses on language in order to settle the empirical question. Language constitutes Dasein's openness to truth. The claim that animals lack world can be justified in terms of their lack of language: 'Because plants and animals are lodged in their respective environments but are never placed freely into the clearing of being which alone is "world", they lack language' (GA 9: 326/248-49). Hence I think Heidegger can agree with the central idea of Deacon (I997: 22): 'My extravagant claim to know what other species cannot know rests on evidence that symbolic thought does not come innately built in, but develops by internalizing the symbolic process that underlies language. So species that have not acquired the ability to communicate symbolically cannot have acquired the ability to think this way either'. Similarly, Davidson (200I: 95) thinks propositional attitudes exceed a merely animal way of being: 'This raises the question how to tell when a creature has propositional attitudes; snails, we may agree, do not, but how about dogs or chimpanzees? The question is not entirely empirical, for there is the philosophical question what evidence is relevant to deciding when a creature has propositional attitudes'. He thinks we are justified in attributing reason to humans alone because 
humans alone have language (200I: $96 \mathrm{nI}$ ). That language reveals world openness, or at least an attribute uniquely human, is a position that enjoys a following among some scientists and notable philosophers.

Mitchell calls our attention to a passage dating from I928-29 in which Heidegger discusses the ontogeny of Dasein. As Mitchell notes, Heidegger approaches both animals and infants privatively, by beginning with mature Dasein (GA 27: I 23). The baby is in a 'dim state', (Dämmerzustand) interested chiefly in sleep, food, and warmth. When Dasein is in this state, entities cannot quite show themselves as such:

The dim state in which such an early life is does not mean that there is no relation to entities, but only that this relating of oneself to . . . has no specific aim. The being near entities is still clouded to some extent, still not cleared, so that this Dasein can make no determinate use of entities, near which it always is by its very essence. (GA 27: I 26)

Mitchell (20I I: 84) thinks Heidegger here compromises his claim that Dasein differs from animals, because he recognizes degrees to Dasein: 'The category that is supposed to be preserved against contamination by an animal other . . . is already compromised. Not all humans are alike'. However, there is no contradiction in maintaining both of the following:

(I) There is a difference in kind between the animal, tied to an environment, and the human infant, destined for world.

(2) There is no difference in kind between the infant, not yet matured, and the child who has matured.

The first proposition sorts kinds of species based on the kind of environment they typically access in their adult form. The second sensibly maintains that developmental stages within a species do not constitute different species; therefore, developmental stages cannot constitute a different kind of species. In this way, it is not correct to say that Heidegger has 'contaminated' his categories. Additionally, some research supports the view that preverbal infants can do something chimpanzees cannot: communicate about absent things (Liszkowski et al. 2009: 654-60). Also, unlike dogs and chimpanzees, human children teach themselves to speak through eavesdropping, not training (Bloom 2000). Philosophically, we can say that infants are destined for language because of the kind of being that they are (Engelland 20I4). Ontogeny may be analogous to phylogeny, but there is this important difference: ontogeny is seamless, concerning a single being, while phylogeny concerns a sequence of numerically distinct beings. This means that there is no place within ontogeny for the advent of a difference in kind, but there is a place within phylogeny for just such a difference.

While the very idea of a difference in kind seems undermined by the fact of common ancestry, Heidegger suggests an analogy to make it more palatable. Any animal, even the simplest, differs in kind from a rock, for the animal has 
an environment. The transition from nonlife to life is not a continuum but a difference in kind. Analogously, the transition from environment to world is not a continuum but a difference in kind. The linguists Derek Bickerton (2009: 9) and Michael Corballis (20II: I 80) provide another analogy. Though we can point to intermediary forms between aquatic insects and flying insects, the break between them is undeniable: either a given species can fly or it cannot. Both think such a difference is compatible with ordinary evolutionary processes. Even Aristotle, who canonically distinguishes ontological gulfs in nature (nonliving to living, living to perceiving, perceiving to understanding), recognizes the presence of intermediate forms (Aristotle, History of Animals, 8.I). We can see that certain molecules, say, are intermediate between chemistry and biology without compromising the fundamental difference between nonliving beings and living ones, because the meaning of the part is determined by the whole of which it is a part. The recognition that some animals, e.g., dogs, chimpanzees, and dolphins, are closer to Dasein than other animals does not undermine the difference in kind between Dasein and animality. A number of scientists, while not questioning the evolutionary continuum, nonetheless do not hesitate to identify a 'gap' between humans and other animals in three areas: behavior, mind, and language (for behavior, see Tomasello [2009] and Kappeler and Silk [2010]; for mind, see Penn, Holyoak, and Povinelli [2008]; and for language, see Hauser, Chomsky, and Fitch [2002], Bickerton [2009], and Deacon [1997]). Philosophical methodology, attentive to the theme of truth and knowledge, can say more: there is indeed a difference in kind between humans and other animals, because there is a difference in kind between environment and world; language is essential to world, and even the higher animals do not have language. Biologically, there is a gap in the continuum; philosophically, there is no continuum at all.

\section{The Principle of Wholism}

Supposing there is a difference in kind between environment and world, why does Heidegger locate the difference between animals and Dasein rather than locate the difference within human nature between animality and rationality? Heidegger (GA 26: 21 2/I 66) briefly flirts with dualism according to which the human body is part of nature while Dasein transcends nature, but his considered view is that openness to being defines Dasein as a whole, the body included. Subscribing to the principle of wholism, Heidegger says that the human body is what it is because of openness to being.

In I929, he expresses the principle as follows: 'Wholeness means that the organism is not an aggregate, composed of elements or parts, but that the growth and the construction of the organism is governed by this wholeness in each and every stage' (GA 29/30: 380/26I). The wholeness of a living being, then, is not the sum of the parts but is instead the governing principle of the parts. The irreducibility of the whole stands in contrast to the 'increasingly powerful, purely analytical method in morphology and physiology' that regards the whole as an aggregate of parts: 
In accordance with this method it was believed—and in part is still believed today - that we can build up the organism through recourse to its elementary constituents without first having grasped the building plan, i.e., the essence of the organism, in its fundamental structure and without keeping this structure in view as that which guides the construction. (GA 29/30: 378-379/260)

Heidegger equally rejects vitalism, the view that some immaterial force accounts for an organism, and he thinks that the whole is the part's reason for being (GA 29/30: 278/I89).

Twenty years later, Heidegger returns to this theme in the 1949 Bremen Lectures. The part-whole relationship of a machine and a living being differ in essential respects. He terms the former 'piece' (das Stück) and the latter 'part' (der Teil). A piece is uniform and replaceable, but a part participates in the whole. 'The part joins, with other parts, into the whole. It takes part in the whole, belongs to it. The piece on the other hand is separate and, as what it is, is sectioned off against other pieces' (GA 79a: 36/276). Pieces do not participate in the whole and so can be exchanged at will, but parts belong to the whole. Heidegger presents his own hand as an example of a part: 'my hand is not a piece of me. I myself am completely in each respective gesture of the hand' (GA 79a: 37/276). According to wholism, the living being is not a machine composed of pieces. The whole is greater than the sum of the parts, and each part embodies the whole. While such a view is not widely shared in today's scientific community, Denton and colleagues (2013) argue that wholism or organicism may be on the ascendency due to the failure of the mechanical model to explain the living cell.

Heidegger denies the relevance of the morphological similarities between human beings and other primates, because he views the body and its parts in terms of the environmental relation: 'Apes, too, have organs that can grasp, but they do not have hands' (GA 8: I8/I6). Heidegger understands the hand in terms of the essential human task of disclosedness and language. 'The hand exists as hand only where there is disclosure and concealment' (GA 54: I I 8/80). Accordingly, we need to look toward language and being, not zoological research, for the origin of the hand: 'The hand sprang forth only out of the word and together with the word' (GA 54: I I 8-19/80). Gestures are an important part of language, and hands enable us to make things. Even though the hand has antecedents in the fossil record, what it is to be a hand makes sense only in light of Dasein's unique task of disclosing being (GA 8: I 8-I9/I6).

Do Heidegger's claims here square with the empirical evidence? Put in Heidegger's terms, are chimpanzees capable of disclosive gesturing? Michael Tomasello (2008: 37-38), an evolutionary psychologist, maintains that chimpanzees do not gesture disclosively. They will reach out to objects that they want, but they do not do what human infants do, namely, point to things they find interesting: 
No apes in any kind of environment produce, either for other apes or for humans, acts of pointing that serve functions other than the imperative function. That is, they do not point declaratively to simply share interest and attention in something with another individual (Gomez 2004), and they do not point informatively to inform another of something she might want or need to know-as human infants do from very early in ontogeny.

The lack of disclosive gesturing stems from a basic difference between human cooperative communication and nonhuman communication. In this respect, Rakoczy and Tomasello (2007) criticize Searle's 'promiscuous' attribution of collective intentionality to all the social animals. The ape gesture reaches out to the object desired, but it does not disclose it as such (Tomasello 2003: I I).

\section{Developing the Distinction between Condition and Cause}

Up to this point, I have defended Heidegger's account. I would now like to remedy a shortcoming. The oddest part of Heidegger's account of Dasein is the body. He admits its kinship with animals yet denies that it is an animal body. He thinks the meaning of the body comes from openness to being; handicraft, gesturing, dancing, etc. are what they are due to openness to being (GA 8: I 8-I9/I6-I7). But what of the humdrum activity of the internal organs and such things as DNA? Certainly the roles they play are identical to the roles played by the parts of many other animals. How do such things relate to Dasein's openness to being?

In a lecture course dating from the early I930s, he argues that the natural body of Dasein is sui generis. Due to freedom, Dasein stands either above or below the animal:

Man can never be an animal, i.e., can never be nature, but is always either over the animal, or, precisely as human, under it (whereupon we say that man becomes 'like an animal'). Since nature does not have the inner elevation of existence which belongs to being-human as being out beyond oneself [Über-sich-hinaus-sein], it is incapable of falling. (GA 34: 236/169)

This dual possibility thoroughly determines the bodily being of Dasein, which makes the body of Dasein differ from that of any animal. Now, we can abstract from human freedom and openness to being and then the human body appears to be of the same kind as the rest of nature. Heidegger cautions, however, that the abstracted human body is still not identical with animal bodies:

The living body [Leib] belongs to the Dasein of man. Being-there [Dasein], in the sense of existence, is a fundamentally different way of being to that of nature. Only by disregarding the specifically human character 
of the living human body can this become something analogous to nature (not nature as such, but working in like manner). (GA 34: 23637/169)

At the same time, Heidegger cannot avoid saying that Dasein does in fact participate in nature, albeit in a sui generis manner: 'Nature is primordially there $[d a]$ in attunedness. As soon as man exists, through his living body he is crowded around by what is sensible and sensed. This means that he bodily participates, although in his own way, as nature within the totality of nature' (GA 34: 237/r69). How can we relate this commonness and uniqueness?

Heidegger's most helpful suggestion comes in a spirited critique of National Socialist ideologue Erwin Kolbenheyer on January 30, 1933. To counter Kolbenheyer's reductive views, Heidegger distinguishes between bodily life as the 'supporting ground' and openness to being as the 'determining ground':

Even if bodily life is in a certain way the supporting ground of human Being and of the ethnic sequence of its generations, this still does not yet prove that the supporting ground also has to be the determining ground, or even that it can be. (GA 36/37: 210/160)

Dasein takes up the bodily being as the supporting ground but determines it for a new end that thoroughly transfigures its meaning. With this distinction, Heidegger restates the classical distinction between condition and cause. ${ }^{6}$ I think we can amplify Heidegger's suggestion and his appropriation of the distinction to say the following: the meaning of our bodies is determined by our openness to being; yet these bodies themselves, including the feats of physiology, chemistry, and physics they accomplish, are conditions for our openness. In the same way that animality transfigures materiality even though it would not be possible without it, so Dasein transfigures animality even though it would not be possible without it. The internal organs function in identical ways to those of other animals, but they contribute to a whole whose significance is radically different. Even basic bodily activities, such as perceiving (as seeking to know), eating (as interpersonal dining), and reproducing (as interpersonal commitment), are quite different for us due to our unique way of being. As a condition for being open to being, Dasein must be an animal, even though being open to being changes the meaning of animality. In Heidegger's terminology, while there are no ontic explanations for the ontological, there are yet ontic conditions for the ontological.

How should we construe the relation between the condition and the cause? The ontological changes the meaning of the ontic conditions. To see why this is the case, consider the shortcoming of MacIntyre's approach. Though he criticizes Heidegger's discussion of human difference, he does acknowledge something specifically human enabled by language. In his view, dolphins can have reasons

6 See Plato, Phaedo, 96a-99e, and Aristotle, Physics, 2.9. The distinction between condition and cause recurs in Heidegger's seminars with psychologists (I987: 200/I 5 5). Paul Ricoeur (2002: 202) likewise employs language of condition and cause to articulate the relation of brain and thought. 
for acting, but only humans can evaluate reasons for acting: 'The child moves beyond its initial animal state of having reasons for acting in this way rather than that towards its specifically human state of being able to evaluate those reasons, to revise them or to abandon them and replace them with others' (I99I: 9I and 53-57). What he fails to see is that this ability to evaluate reasons changes the nature of the reasons. In mature humans, reasons for acting take their bearing from the fact that they can be evaluated in terms of the human good. They are not geared essentially to environmental goods as with nonhuman animals; reasons for action are situated within the context of an overall aim of achieving a complete life. 'Reasons for acting' in animals and humans are two different kinds of things, because openness to truth changes the meaning of Dasein's animal inheritance. Heidegger's principle of wholism invites us to understand the human being as an integral whole in terms of openness to being rather than as a general animality to which something specifically human is subsequently appended.

\section{Conclusion}

In the opening of the Selfish Gene, biologist Richard Dawkins (I976: I) memorably writes: 'Living organisms had existed on earth, without ever knowing why, for over three thousand million years before the truth finally dawned on one of them. His name was Charles Darwin.' Heidegger would insist on a precision: truth did not occur to Darwin because he was an organism. Darwin could be Darwin because he was Dasein, open to the truth of things, and the truth he discovered was not an idiosyncrasy of the species, Homo sapiens. In this way, Heidegger argues that the human environment, characterized by interpersonal meaning and truth, differs in kind from animal environments. Heidegger rejects the view that humans are just another species, since such a view neglects the normativity of truth, something that, among other things, is a necessary presupposition for science. However, he also rejects what the neurologist Antonio Damasio (I994: 249) calls 'Descartes' error', namely 'the abyssal separation between body and mind'. There is no hint of substance dualism in Heidegger's mature thinking on these topics. Dasein as a whole is defined in reference to this openness to being and truth, and Dasein as a whole is separated from animals by an abyss. I emphasized his distinction between condition and cause to do justice to our animal inheritance while owning up to our unique position in all of nature: we are the ones who can transcend biological relevance and understand the truth of things together with others. On my reading, Heidegger does not wish to deny the evolution of Dasein. Our mammalian frame and genetic heritage testify to the lowliness of our ancestry. He only denies that it can tell us what it means to be human.

I argued that Heidegger subscribes to the following theses:

I. Organism and environment are reciprocally related.

2. The human environment is the world of meaning and truth, which is constituted by language. 
3. Lacking language, animals lack world.

4. The difference between world and environment cannot be denied without making truth relative to human biology and without making the normativity of truth unintelligible.

5. The whole organism determines the meaning of the part; in the case of human beings, openness to world determines the meaning of their bodies.

6. The biology of the human being constitutes a condition (not a cause) for world openness.

CHAD ENGELLAND

UNIVERSITY OF DALLAS

cengelland@udallas.edu

\section{References}

Bickerton, Derek. (2009) Adam's Tongue: How Humans Made Language, How Language Made Humans. New York: Hill and Wang.

Bloom, Paul. (2000) How Children Learn the Meanings of Words. Cambridge, MA: MIT Press.

Calarco, Matthew. (2008) Zoographies: The Question of the Animal from Heidegger to Derrida. New York: Columbia University Press.

Carman, Taylor. (2003) Heidegger's Analytic: Interpretation, Discourse, and Authenticity in 'Being and Time'. Cambridge, UK: Cambridge University Press.

Corballis, Michael. (20I I) The Recursive Mind: The Origins of Human Language, Thought, and Civilization. Princeton, NJ: Princeton University Press.

Crowell, Steven Galt. (2002) 'Does the Husserl/Heidegger Feud Rest on a Mistake? An Essay on Psychological and Transcendental Phenomenology'. Husserl Studies, I 8, I23-40.

Crowell, Steven Galt. (2013) Normativity and Phenomenology in Husserl and Heidegger. Cambridge, UK: Cambridge University Press.

Dahlstrom, Daniel. (1994) 'Heidegger's Method: Philosophical Concepts as Formal Indications'. Review of Metaphysics, 47, 775-95.

Damasio, Antonio. (1994) Descartes' Error: Emotion, Reason, and the Human Brain. New York: HarperCollins.

Darwin, Charles. (1952a) The Origin of Species. In Darwin, vol. 49 of Great Books of the Western World. Chicago: Encyclopedia Britannica.

Darwin, Charles. (1952b) The Descent of Man. In Darwin, vol. 49 of Great Books of the Western World. Chicago: Encyclopedia Britannica.

Davidson, Donald. (200I) 'Rational Animals'. In Subjective, Intersubjective, Objective. Oxford: Clarendon Press.

Dawkins, Richard. (1976) The Selfish Gene. Oxford: Oxford University Press.

Deacon, Terrence. (1997) The Symbolic Species: The Co-evolution of Language and the Brain. New York: Norton.

Denton, Michael, Govindasamy Kumaramanickavel, and Michael Legge. (2013) 'Cells as Irreducible Wholes: The Failure of Mechanism and the Possibility of an Organicist Revival'. Biology and Philosophy, 28, 3 I-52.

Engelland, Chad. (20I2) 'Disentangling Heidegger's Transcendental Questions'. Continental Philosophy Review, 45, 77-100.

Engelland, Chad. (20I4) Ostension: Word Learning and the Embodied Mind. Cambridge, MA: MIT Press. 
Gadamer, Hans-Georg. (1998) Truth and Method. Rev. ed. Translated by Joel Weinsheimer and Donald G. Marshall. New York: Continuum.

Gómez, Juan Carlos. (2004) Apes, Monkeys, Children, and the Growth of Mind. Cambridge, MA: Harvard University Press.

Hauser, Marc D., Noam Chomsky, and W. Tecumseh Fitch. (2002) 'The Faculty of Language: What Is It, Who Has It, and How Did It Evolve?'. Science, 298, I 569-79.

Heidegger, Martin. GA 8. (2002) Was Heisst Denken? Edited by Paola-Ludovika Coriando. Frankfurt am Main: Vittorio Klostermann. Translated by J. Glenn Gray as What Is Called Thinking? (New York: Harper \& Row, I968).

Heidegger, Martin. GA 9. (I976) 'Brief über den Humanismus'. In Friedrich-Wilhelm von Herrmann (ed.), Wegmarken. Frankfurt am Main: Vittorio Klostermann. Translated by Frank Capuzzi as 'Letter on Humanism'. In William McNeill (ed.), Pathmarks (Cambridge: Cambridge University Press, I998).

Heidegger, Martin. GA 24. (1975) Die Grundprobleme der Phänomenologie. Edited by Friedrich-Wilhelm von Herrmann. Frankfurt am Main: Vittorio Klostermann. Translated by Albert Hofstadter as The Basic Problems of Phenomenology. Bloomington, IN: Indiana University Press, 1982.

Heidegger, Martin. GA 26. (1978) Metaphysische Anfangsgründe der Logik im Ausgang von Leibniz. Edited by Klaus Held. Frankfurt am Main: Vittorio Klostermann. Translated by Michael Heim as The Metaphysical Foundations of Logic. Bloomington, IN: Indiana University Press, I984.

Heidegger, Martin. GA 27. (1996) Einleitung in die Philosophie. Edited by Otto Saame and Ina Saame-Speidel. Frankfurt am Main: Vittorio Klostermann.

Heidegger, Martin. GA 29/30. (1983) Die Grundbegriffe der Metaphysik. Edited by Friedrich-Wilhelm von Herrmann. Frankfurt am Main: Vittorio Klostermann. Translated by William McNeill and Nicholas Walker as The Fundamental Concepts of Metaphysics. Bloomington, IN: Indiana University Press, I995.

Heidegger, Martin. GA 34. (I997) Vom Wesen der Wabrheit: Zu Platons Höhlengleichnis und Theätet. Edited by Hermann Mörchen. Frankfurt am Main: Vittorio Klostermann. Translated by Ted Sadler as The Essence of Truth: On Plato's Cave Allegory and Theaetetus. London: Continuum, 2002.

Heidegger, Martin. GA 36/37. (200I) Sein und Wahrheit. Edited by Hartmut Tietjen. Frankfurt am Main: Vittorio Klostermann. Translated by Gregory Fried and Richard Polt as Being and Truth. Bloomington, IN: Indiana University Press, 2010.

Heidegger, Martin. GA 40. (I983) Einführung in die Metaphysik. Edited by Petra Jaeger. Frankfurt am Main: Vittorio Klostermann. Translated by Gregory Fried and Richard Polt as Introduction to Metaphysics. New Haven, CT: Yale University Press, 2000.

Heidegger, Martin. GA 54. (I982) Parmenides. Edited by Manfred S. Frings. Frankfurt am Main: Vittorio Klostermann. Translated by André Schuwer and Richard Rojcewicz as Parmenides. Bloomington, IN: Indiana University Press, 1992.

Heidegger, Martin. GA 56/57. (1987) Zur Bestimmung der Philosophie. Edited by Bernd Heimbüchel. Frankfurt am Main: Vittorio Klostermann. Translated by Ted Sadler as Towards the Definition of Philosophy. New York: Continuum Press, 2000.

Heidegger, Martin. GA 79a. (1994) 'Einblick in Das Was Ist: Bremer Vorträge I949'. In Petra Jaeger (ed.), Bremer und Freiburger Vorträge. Frankfurt am Main: Vittorio Klostermann. Translated by Jerome Veith as 'Insight into That Which Is: Bremen Lectures'. In Günter Figal (ed.), The Heidegger Reader (Bloomington: Indiana University Press, 2009).

Heidegger, Martin. ([1927] 200I) Sein und Zeit. I8th ed. Tübingen: Max Niemeyer Verlag. Translated by John Macquarrie and Edward Robinson as Being and Time. New York: Harper \& Row, I962.

Heidegger, Martin. (1987) Zollikoner Seminare. Edited by Medard Boss. Frankfurt am Main: Vittorio Klostermann. Translated by Franz Mayr and Richard Askay as Zollikon Seminars. Edited by Medard Boss. Evanston, IL: Northwestern University Press, 200I. 
Husserl, Edmund. ([1913] 1998). Ideas. Ideas Pertaining to a Pure Phenomenology and to a Phenomenological Philosophy. First Book: General Introduction to a Pure Phenomenology. Translated by F. Kersten. Dordrecht: Kluwer Academic Publishers.

Husserl, Edmund. ([r900] 2000a) Logical Investigations. Vol. I. Translated by J. N. Findlay. Amherst, NY: Humanity Books.

Husserl, Edmund. ([т90г] 2000b) Logical Investigations. Vol. 2. Translated by J. N. Findlay. Amherst, NY: Humanity Books.

Kappeler, Peter, and Joan Silk, eds. (2010) Mind the Gap: Tracing the Origins of Human Universals. Berlin: Springer.

Kendal, Jeremy R., Jamshid J. Tehrani, and John Odling-Smee, eds. (20II) 'Human Niche Construction'. Philosophical Transactions of the Royal Society B, 366, 784-934.

Krell, David Farrell, ed. (1993) Heidegger: Basic Writings. New York: Harper \& Row.

Lewontin, Richard. (I99I) Biology as Ideology: The Doctrine of DNA. New York: HarperCollins.

Lewontin, Richard. (2000) The Triple Helix: Gene, Organism, and Environment. Cambridge, MA: Harvard University Press.

Liszkowski, Ulf, Marie Schäfer, Malinda Carpenter, and Michael Tomasello. (2009) 'Prelinguistic Infants, but Not Chimpanzees, Communicate About Absent Entities'. Psychological Science, 20, 654-60.

MacIntyre, Alisdair. (1999) Dependent Rational Animals: Why Human Beings Need the Virtues. Chicago: Open Court.

McDowell, John. (I994) Mind and World. Cambridge, MA: Harvard University Press.

McNeill, William. (I999) 'Life Beyond the Organism: Animal Being in Heidegger's Freiburg Lectures, I929-1930'. In H. Peter Steeves (ed.), Animal Others: On Ethics, Ontology, and Animal Life (Albany, NY: State University of New York Press), I97-248.

Mitchell, Andrew. (20I I) 'Heidegger's Later Thinking of Animality: The End of World Poverty'. Gatherings: The Heidegger Circle Annual, I, 74-85.

Nietzsche, Friedrich. (I968) Will to Power. Translated by Walter Arnold Kaufmann and R. J. Hollingdale. New York: Random House.

Odling-Smee, F. John, Kevin N. Laland, and Marcus W. Feldman. (2003) Niche Construction: The Neglected Process in Evolution. Princeton, NJ: Princeton University Press.

Penn, Derek C., Keith J. Holyoak, and Daniel J. Povinelli. (2008) 'Darwin's Mistake: Explaining the Discontinuity between Human and Nonhuman Minds'. Behavioral and Brain Sciences, 3 I, I09-78.

Rakoczy, Hannes, and Michael Tomasello. (2007) 'The Ontogeny of Social Ontology: Steps to Shared Intentionality and Status Functions'. In Savas L. Tsohatzidis (ed.), Intentional Acts and Institutional Facts: Essays on John Searle's Social Ontology (Dordrecht: Springer), I I 3-38.

Ricoeur, Paul. (2000) What Makes Us Think? A Neuroscientist and a Philosopher Argue About Ethics, Human Nature, and the Brain. Translated by M. B. DeBevoise. Princeton, NJ: Princeton University Press.

Searle, John. (2005) 'The Phenomenological Illusion'. In Maria E. Reicher and Johann Christian Marek (eds.), Erfahrung und Analyse (Vienna: ÖBV \& HPT), 3 I7-36.

Shockey, R. Matthew. (2010) 'What's Formal about Formal Indication? Heidegger's Method in Sein und Zeit'. Inquiry, 53, 525-39.

Sokolowski, Robert. (2008) Phenomenology of the Human Person. New York: Cambridge University Press.

Stegmaier, Werner. (1987) 'Darwin, Darwinismus, Nietzsche: Zum Problem der Evolution'. Nietzsche-Studien, I6, 264-87.

Tomasello, Michael. (2003) Constructing a Language: A Usage-Based Theory of Language Acquisition. Cambridge, MA: Harvard University Press.

Tomasello, Michael. (2008) Origins of Human Communication. Cambridge, MA: MIT Press.

Tomasello, Michael. (2009) Why We Cooperate. Cambridge, MA: MIT Press.

Uexküll, Jakob von. (I92I) Umwelt und Innenwelt der Tiere. $2 \mathrm{~d}$ ed. Berlin: Springer. 